\title{
Expedition 302 geophysics: integrating past data with new results ${ }^{1}$
}

\author{
Martin Jakobsson, ${ }^{2}$ Tom Flodén, ${ }^{2}$ and the Expedition 302 Scientists $^{2}$
}

\section{Chapter contents}

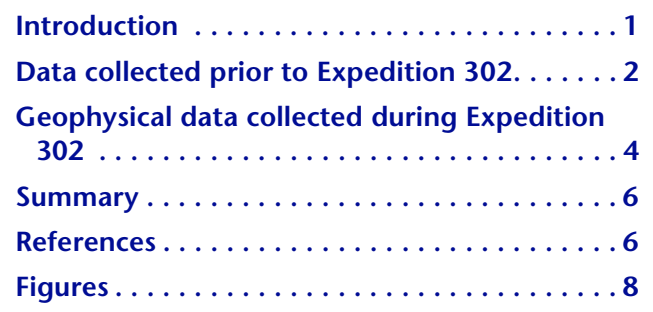

'Jakobsson, M., Flodén, T., and the Expedition 302 Scientists, 2006. Expedition 302 geophysics: integrating past data with new results. In Backman, J., Moran, K., Mclnroy, D.B., Mayer, L.A., and the Expedition 302 Scientists, Proc. IODP, 302:

Edinburgh (Integrated Ocean Drilling Program Management International, Inc.). doi:10.2204/ iodp.proc.302.102.2006

'Expedition 302 Scientists' addresses.

\section{Introduction}

In preparation for IODP Expedition 302, Arctic Coring Expedition (ACEX), a site survey database comprising geophysical and geological data from the Lomonosov Ridge was compiled. The accumulated database includes data collected from ice islands, icebreakers, and submarines from 1961 to 2001. In addition, seismic reflection profiles were collected during Expedition 302 that complement the existing seismic reflection data and facilitate integration between the acoustic stratigraphy and the Expedition 302 drill cores. An overview of these data is presented in this chapter.

It is well recognized that collecting geophysical data in ice-covered seas, in particular the Arctic Ocean, is a challenging endeavor. This is because much of the Arctic Ocean is continuously covered with ice thicknesses that vary from 1 to $6 \mathrm{~m}$. Over the continental shelves, sea ice can be absent during summer months, but it is present year-round in the central basins. This ice cover is the most dominant feature of the Arctic Ocean environment. It circulates in the ocean basin in two main circulation patterns: the Transpolar Drift and the Beaufort Gyre (see the "Expedition 302 summary" chapter; Rudels et al., 1996).

Expedition 302 sites are located within the less severe of these two ice circulation systems, the Transpolar Drift, which primarily moves sea ice from the shelves where it is formed (the Laptev and East Siberian Seas) across the basin and exits through the Fram Strait. During late summer, concentrations of Arctic sea ice can be $<100 \%$ (10/10 ice cover), making it possible for icebreakers to operate. Average ice concentrations in the central Arctic Ocean during summer months can locally vary from partially open water (6/ $10)$ to completely ice covered (10/10). This sea-ice cover can move at speeds up to $0.5 \mathrm{kt}$.

Early Arctic Ocean geophysical exploration was performed from ice-drift stations (Weber and Roots, 1990). However, the tracks from these drifting ice stations were controlled "by the whims of nature" (Jackson et al., 1990), preventing detailed, systematic surveys of predetermined target areas. These ice-drift stations were set up on stable icebergs that were trapped in sea ice and moved generally with the large drift patterns, but locally they were erratic, so preselected locations could not be surveyed. In the late 1980s, single icebreakers began to be used for oceanographic survey work in the Arctic Ocean. Between 1991 and 2001, four scientific icebreaker expeditions to the Lomonosov Ridge took place. 
These cruises all experienced local sea-ice conditions varying between $8 / 10$ and 10/10. During these expeditions, towed geophysical equipment was occasionally damaged or lost, either because of a rapidly closing wake caused by local ice pressure or because ice had cut the air gun array.

Conventionally powered icebreakers reached as far as the North Pole for the first time during the 1991 Expedition (Andersen and Carlsonn, 1992; Fütterer, 1992). Geophysical results from this expedition collected two important reflection profiles, AWI-91090 and AWI-91091, that crossed the Lomonosov Ridge between $87^{\circ}$ and $88^{\circ} \mathrm{N}$. These profiles imaged a $\sim 50$ $\mathrm{m}$ thick, well-stratified and apparently undisturbed drape of sediments overlying a prominent acoustic unconformity (Jokat et al., 1992) that spawned the idea to conduct a paleoceanographic drilling expedition to this Ridge.

The use of US Navy nuclear submarines for geophysical mapping was implemented through the Science Ice Exercise program (SCICEX) (Newton, 2000). The development of the Seafloor Characterization and Mapping Pods (SCAMP), which hold a Chirp subbottom profiler, swath bathymetric profiler, and side scan sonar, was an essential part of the SCICEX program (Chayes et al., 1996). In 1999, the Lomonosov Ridge geophysical database was augmented with acoustic data acquired during the SCICEX program using the SCAMP system mounted on the US nuclear submarine USS Hawkbill (Edwards and Coakley, 2003).

\section{Data collected prior to Expedition 302}

A chronologically arranged overview of several, but not all, geophysical data sets from the Lomonosov Ridge is presented here. These data sets were collected from ice islands (ARLIS II and LOREX), submarines (SCICEX), and icebreakers (all others). Locations of the seismic lines from these expeditions are shown in Figure F1.

\section{ARLIS II 1961-1965}

The second US Navy Arctic Research Laboratory Ice Station (ARLIS II) was deployed on an ice island in $1961 \sim 350 \mathrm{~km}$ northwest of Point Barrow, Alaska (Ostenso and Wold, 1977). During the ice island's drift journey toward the Fram Strait, it reached its northernmost point on the Lomonosov Ridge flank, facing the Makarov Basin, in December 1963 (Fig. F1). The scientific program included bathymetric measurements, gravity observations, and continuous seismic reflection profiling. Reprocessing of the seis- mic reflection data (Weber and Sweeney, 1985) resulted in the interpretation of a $60 \mathrm{~m}$ thick section of conformable sediments draping the Lomonosov Ridge plateau along the ARLIS II's first crossing of the ridge plateau from the Makarov Basin side. Further along the oblique drift track across the Ridge (Fig. F1), the thickness of the conformably draped and well-stratified sediments increased to $>850 \mathrm{~m}$ on the Ridge's flat-topped crest (Weber and Sweeney, 1985).

\section{LOREX 1979}

North of the ARLIS II crossing of the Lomonosov Ridge, seismic reflection profiling was conducted from another drifting ice island in 1979, during the Canadian the Lomonosov Ridge Experiment (LOREX) (Weber, 1979) (Fig. F1). An air gun with a $0.164 \mathrm{~L}\left(10 \mathrm{inch}^{3}\right)$ chamber was deployed as the seismic source through a hole in the ice, in addition to a multichannel system for deeper penetration using explosive charges (Weber, 1979). LOREX also installed a $3 \mathrm{kHz}$ subbottom profiler for higher resolution seismic acquisition (Weber, 1979). The seismic reflection data revealed the geological characteristics of the Lomonosov Ridge along the ice station's crossing of a narrow section of the ridge near the North Pole (Fig. F1). The conclusion from these data was that the Ridge consisted of a series of tilted en-echelon fault blocks with their crests covered by thin ( $<75 \mathrm{~m}$ thick) drapes of unconsolidated sediments (Weber and Sweeney, 1985) (Fig. F2). Furthermore, substantial sediment erosion by currents was suggested in the area where the LOREX ice stations crossed the Lomonosov Ridge (Blasco et al., 1979).

\section{Arctic Ocean 1991/ARK-VIII/3}

After the completion of the LOREX project in 1979, it took $12 \mathrm{y}$ before the next seismic reflection data were acquired over the Lomonosov Ridge. This occurred during the Arctic 1991 expedition (Fütterer, 1992; Jokat et al., 1992). The icebreakers Polarstern (Germany) and Oden (Sweden) conducted this expedition together. Seismic equipment was towed behind the Polarstern using a setup designed to function in Arctic sea ice. This configuration was based on previous Arctic seismic survey experiences that proved successful in this challenging environment (Grantz et al., 1986).

Towing equipment behind an icebreaker in the central Arctic pack ice, often approaching 10/10 ice coverage, is problematic. The icebreaking strategy is typically based on following existing leads-that is, by traveling along the periphery of larger ice floes. Because of this strategy, the ship's track becomes highly irregular, requiring the streamer length to be shortened to a few hundred meters. 
In situations where the ship is breaking ice, the freshly broken lead may close rapidly behind the icebreaker and trap the towed streamer. For this situation, a short streamer is also necessary. Moreover, meter-sized pieces of broken ice floes are continuously forced under the icebreaker's hull. These pieces can impact, with great force, seismic equipment towed near the ship.

During the Arctic 1991 expedition, the seismic source consisted of two $3 \mathrm{~L}\left(\sim 183 \mathrm{inch}^{3}\right)$ air guns that were suspended below a 1 ton weight to keep the air guns as close to the ship's fantail as possible (Jokat et al., 1992). A $300 \mathrm{~m}$ long 12-channel streamer was deployed as a receiver. Seismic reflection profiles were successfully acquired over the Lomonosov Ridge using this setup in $7 / 10$ to $8 / 10$ ice conditions (Jokat et al., 1992). In addition to seismic reflection, sonobuoys were deployed during this expedition to map the velocity structure of the Lomonosov Ridge sediments and bedrock (Jokat et al., 1992). Two of the seismic reflection profiles, AWI-91090 and AWI91091, crossed the Ridge crest completely at about $87^{\circ} 55^{\prime} \mathrm{N}$ and $87^{\circ} 40^{\prime} \mathrm{N}$, respectively (Figs. F1, F3). These two profiles provided the first high-quality images of the $<450 \mathrm{~m}$ thick, well-stratified, and apparently undisturbed drape of sediments (Jokat et al., 1992) on the Ridge crest. These two lines were subsequently used to identify proposed paleoceanographic drill sites.

During the Arctic 1991 expedition, subbottom profiling data were also acquired continuously using the Polarstern's hull-mounted Parasound system, a parametric high-resolution subbottom profiler that operates in a frequency range between 2.5 and $5.5 \mathrm{kHz}$ (Fütterer et al., 1992). The Parasound records along the AWI-91090 and AWI-91091 profiles showed that, even at higher resolution, the uppermost $\sim 30-40 \mathrm{~m}$ of the Lomonosov Ridge stratigraphy appeared undisturbed (Fig. F4). The Polarstern was also equipped with an Atlas Hydrosweep multibeam bathymetric sonar that provided additional depth information of the Lomonosov Ridge crest along the 1991 expedition track (Fütterer et al., 1992). These data were incorporated into the International Bathymetric Chart of the Arctic Ocean (IBCAO) (Jakobsson et al., 2000), which provided the general bathymetry of the Lomonosov Ridge for Expedition 302.

\section{Arctic Ocean 1996/ARK-XII/1}

The Oden and Polarstern teamed up again during the Arctic Ocean 1996 expedition. The geophysical data consisted of seismic reflection profiling, seismic refraction experiments (Kristoffersen et al., 1997), and high-resolution subbottom profiling using a chirp sonar (Backman et al., 1997). It was the first time that chirp sonar data were collected from the central Arctic Ocean. When compared with the Arctic 1991 expedition, the geophysical surveying was concentrated in areas of the Lomonosov Ridge located closer to the Siberian continental margin (Fig. F1). Seismic reflection profiling was also conducted successfully along a transect crossing the Ridge near the North Pole (Fig. F1). In total, more than $700 \mathrm{~km}$ of seismic reflection data were collected. An air gun array consisting of four sleeve guns with a total volume of $5.5 \mathrm{~L}\left(\sim 336 \mathrm{inch}^{3}\right)$ mounted in a steel cage and depressed by a 1 ton weight was initially used. This array was lost because of impact with ice (Kristoffersen et al., 1997). A lighter depressor foil was subsequently constructed for two spare $3 \mathrm{~L}\left(\sim 183\right.$ inch $\left.^{3}\right)$ Prakla Seismos air guns. The lighter depressor worked well with less risk to the seismic source. A $200 \mathrm{~m}$ 16-channel streamer was towed as the receiver, using an offset of $150 \mathrm{~m}$ behind the icebreaker.

Chirp sonar profiles provided important information about shallow sediment erosion (Fig. F5). Previously unmapped areas of the Ridge crest located between about $85^{\circ} 24^{\prime} \mathrm{N}$ and $87^{\circ} 17^{\prime} \mathrm{N}$ were substantially eroded, indicating that the ridge crest had been affected by ice grounding down to about $1 \mathrm{~km}$ water depth (Jakobsson, 1999; Jakobsson et al., 2001; Polyak et al., 2001). A pronounced unconformity was mapped to show that $>50 \mathrm{~m}$ of the sediment column was estimated to be missing in portions of the eroded areas (Jakobsson, 1999). The chirp sonar data also demonstrated that at water depths $>1 \mathrm{~km}$, the seismic stratigraphy consisted of well-stratified and apparently undisturbed sediments.

Another outcome of the Arctic Ocean 1996 expedition was a largely revised bathymetric portrayal of the Lomonosov Ridge between $85^{\circ} 20^{\prime} \mathrm{N}, 135^{\circ} \mathrm{E}$ and $87^{\circ} 40^{\prime} \mathrm{N}, 155^{\circ} \mathrm{E}$ (Jakobsson, 1999). These data were critical for supplementing the Arctic Ocean bathymetric database used to develop the new IBCAO map (Jakobsson et al., 2000).

\section{ARK-XIV/1a}

The major goal of expedition ARK-XIV/1a in 1998 was to sample and acquire geophysical data from the Alpha Ridge in the Amerasian Arctic Ocean (Jokat, 1998). Because of the extreme ice conditions that prevail in the Alpha Ridge region, two ships were used: the Polarstern as the scientific platform and the Russian nuclear icebreaker Arktika as the support icebreaker. Despite working in extremely hard ice conditions with up to $6 \mathrm{~m}$ thick sea ice, a total of 320 $\mathrm{km}$ of multichannel seismic reflection data was collected from the Alpha Ridge along three profiles, 
showing a sediment thickness ranging from 500 to $1200 \mathrm{~m}$ (Jokat, 2003).

During the return route toward the Laptev Sea, a track was chosen along the strike of the Lomonosov Ridge in more favorable ice conditions. Several profiles were successfully acquired along and crossing the Ridge crest (Jokat, 1998) (Figs. F1, F6). These profiles show a more variable topography of the Ridge south of $85^{\circ} \mathrm{N}$ compared to the 1991 and 1996 survey areas north of $85^{\circ} \mathrm{N}$. The 1998 data also show that the sediment thickness atop the ridge gradually increases toward the Laptev Sea margin. One primary and three alternate Expedition 302 drilling sites were proposed along the 1998 seismic reflection profiles. These alternate sites were selected primarily as backups for ice contingency purposes.

\section{SCICEX 1999}

During the SCICEX 1999 cruise, the US nuclear submarine USS Hawkbill mapped the Lomonosov Ridge without being restricted by Arctic pack ice. A much larger area could be mapped because this ice constraint was eliminated (Edwards and Coakley, 2003) (Fig. F1). The SCAMP system, mounted on the USS Hawkbill, continuously recorded chirp sonar profiles, sidescan data, and swath bathymetric data along a regular survey track over the Lomonosov Ridge. The track was designed to investigate the nature of the erosion of the Ridge crest and acquire additional site survey data near the two primary seismic reflection profiles, AWI-91090 and AWI-91091. The SCAMP chirp sonar data confirmed that erosion was limited to water depths shallower than $1000 \mathrm{~m}$ on the ridge crest (Polyak et al., 2001) and that the area near the two seismic reflection profiles showed an apparently undisturbed sediment stratigraphy (Edwards and Coakley, 2003).

\section{Arctic Ocean 2001}

As of 2001, the Expedition 302 site survey database contained geophysical data that indicated undisturbed sediment sequences at several locations on the Lomonosov Ridge. However, there were no seismic reflection cross-lines on the Ridge, and the Ocean Drilling Program Site Survey Panel requested that these be collected. For this reason, a site survey component was added to a Swedish expedition in 2001 (Kristoffersen et al., 2001). Two generator-injector guns with $8.5 \mathrm{~L}\left(\sim 519\right.$ inch $\left.^{3}\right)$ combined capacity and an 8-channel streamer with an active length of $200 \mathrm{~m}$ were deployed as the seismic reflection system (Kristofferson et al., 2001). Under tough ice conditions, $100 \mathrm{~km}$ of seismic reflection data were collected with the purpose of crossing the previously ac- quired AWI-91091 profile (Fig. F1). The difficult ice conditions reduced the number of survey days from five to three, and $400 \mathrm{~m}$ of hydrophone cable was also damaged.

\section{Geophysical data collected during Expedition 302}

Single-channel seismic reflection and $15 \mathrm{kHz}$ echo soundings profiling were conducted during Expedition 302 to build upon the existing geophysical site survey database in the vicinity of the four drill sites (M0001-M0004) located along profile AWI-91090 (Figs. F1, F7). The acquisition of these additional seismic reflection data had three main objectives:

1. To image the upper $450-500 \mathrm{~m}$ of the Lomonosov Ridge sediment sequence at improved resolution,

2. To cross profile AWI-91090 in the vicinity of Expedition 302 drill sites, and

3. To further extend the seismic database of the Lomonosov Ridge in the vicinity of Expedition 302 drill sites in order to facilitate integration of the Expedition 302 core data with the acoustic stratigraphy on the Lomonosov Ridge as whole.

\section{Methods}

A schematic illustration of the Expedition 302 seismic reflection acquisition and underway postprocessing setup is shown in Figure F8. The individual components are described below.

\section{Navigation}

The seismic acquisition system was installed in a winch compartment located on the Oden's aftdeck. From this location, there was no direct cable access to the ship's navigation system, and, therefore, a separate Ashtech 12-channel Global Positioning System (GPS) receiver was installed to receive positions for the seismic reflection profiling. The GPS antenna was mounted on the aftdeck's starboard side, and all positions were corrected in the Meridata data acquisition software (MDCS) (Fig. F8) to account for the distance between the GPS antenna and the seismic source and streamer.

\section{Seismic reflection}

A PAR 1600 air gun with a $0.65 \mathrm{~L}\left(40\right.$ inch $\left.^{3}\right)$ air chamber and wave shape kit was used as the seismic source. The seismic signal receiver consisted of a single-channel streamer with an active length of $16 \mathrm{~m}$. The streamer contained 100 AQ-1 hydrophone elements and a preamplifier. The shot interval was set to $2.7 \mathrm{~s}$, and, following a time delay of $1.0 \mathrm{~s}$, the re- 
ceived signal was sampled at $4 \mathrm{kHz}$ during a $1.3 \mathrm{~s}$ sweep. Data acquisition was performed using a top unit from Meridata (Fig. F8) connected to a personal computer. All acquired data were stored on a hard disk in the custom Meridata format. Apart from the data acquisition software (MDCS-Meridata data acquisition) (Fig. F8), the system included software for signal post-processing and interpretation (MDPSMeridata processing and interpretation) (Fig. F8).

The seismic source was towed using a specially designed steel depressor as a tow vehicle (Fig. F9) for two main reasons: (1) to keep the seismic source as close to the Oden's fantail as possible to avoid problems with ice and (2) to keep the air guns deeper than the Oden's noisy and turbulent propeller stream. Towing seismic equipment in heavy ice conditions necessitated that proven methods developed from previous Arctic Ocean seismic reflection surveys (Jokat et al., 1992; Kristoffersen, 1997; Kristoffersen et al., 2001) be employed. The streamer was attached to the steel tow vehicle in order to prevent it from being towed into the propeller stream or caught by ice. Between the ship and the steel depressor, the cables were protected from ice by a $25 \mathrm{~m}$ long reinforced plastic hose (Fig. F9). The towed seismic devices were designed to be small so that they could be launched and retrieved quickly.

The Russian nuclear icebreaker Sovetskiy Soyuz assisted during the seismic reflection survey by breaking ice and forming leads ahead of the Oden along the profiling track. This made it possible to keep close to the planned track, although some maneuvers around major floes were unavoidable to keep the two-ship convoy from stopping (Fig. F7).

\section{Bathymetry}

A Marimatech E-Sea Sound MP35 dual-frequency survey echo sounder set to $15 \mathrm{kHz}$ was installed shortly before the Expedition 302 departure. Depths from this echo sounder were continuously logged in the Oden's database during most of Expedition 302. A sound velocity of $1463 \mathrm{~m} / \mathrm{s}$ was used to calculate water depths from the echo soundings.

\section{Results}

\section{Seismic reflection}

Seismic reflection profiling was accomplished on one occasion during Expedition 302. The survey was planned along a track crossing profile AWI-91090 orthogonally at several locations; two of these crossings were located near Sites M0002 and M0003 (Figs. F7, F10). Time did not permit the completion of the entire planned $41 \mathrm{~km}$ track because of ice conditions. However, a total of $22 \mathrm{~km}$ of seismic reflection profiles was acquired at an average ship speed of 2.4 kt (Fig. F7). The initial part of the survey (profiles 48250112-4825026) was conducted in nearly 10/10 sea ice cover and heavy ice pressure, which resulted in a high noise level due to icebreaking and a ship speed too low $(<1 \mathrm{kt})$ for high-quality seismic reflection acquisition. The ice pressure gradually decreased and, as a result, the ship speed could be increased, which improved data acquisition during the remaining survey (Fig. F10).

Following completion of drilling operations at the last site, seismic profiling was planned for $6 \mathrm{~h}$ in the vicinity of Site M0004. However, increasing wind and high ice pressure resulted in an unsuccessful survey. The ship speed could not be maintained above 1 kt because of ice, and only ship noise was recorded.

\section{Bathymetry}

The new Marimatech echo sounder installed on the icebreaker Oden performed poorly during the entire expedition. In the deep areas (depth $=>2000 \mathrm{~m}$ ), practically no useful bathymetry data were collected (drilling operations on the Lomonosov Ridge took place in water depths ranging from 1200 to $1300 \mathrm{~m}$ ). Because the Oden was clearing ice continuously around the drillship Vidar Viking, an abundance of echo soundings could have been collected around each of the drill sites (Fig. F11). Hundreds of crossing track-lines were logged, which made it possible to compare the depth data logged at the crossovers (Figs. F11). The results from this comparison, together with a three-dimensional (3-D) analysis, show the poor performance of the echo sounder (Fig. F12). Because the area had previously been surveyed during the ARK-VIII/3 cruise with Polarstern's Hydrosweep system (Fütterer, 1992), no further efforts were made to make use of the echo sounding data collected during Expedition 302.

\section{Acoustic stratigraphy at Expedition 302 coring sites}

The acoustic stratigraphy in the surveyed area is remarkably consistent. Profile 48250420, which runs along AWI-91090 and passes close to Site M0003, provides a representative view of the seismic stratigraphy (Fig. F10A). The stratigraphic level for the pronounced unconformity identified by Jokat et al. (1992) is marked by a prominent reflector (Fig. F10A, F10B). Profile 48250531 passes $<100 \mathrm{~m}$ from Site M0002 (Fig. F10B), again showing the unconformity as a prominent reflector (Fig. F10B).

Prominent reflectors in the seismic reflection profiles collected during Expedition 302 are readily correlated with reflectors in profile AWI-91090 (Fig. F13). 
Jokat et al. (1995) have divided the upper $~ 450-500$ $\mathrm{m}$ thick and horizontally stratified sediment section of the Lomonosov Ridge stratigraphy into four units (Units LR6-LR3). These units have been interpreted to represent important stages in the Cenozoic evolution of the Lomonosov Ridge and, thus, the Arctic Ocean. Because of its higher resolution, Expedition 302 seismic reflection data provide additional information regarding the acoustic stratigraphy within units LR6-LR3. For example, within unit LR5, a set of reflectors are resolved at higher resolution than earlier data. These reflectors are clearly visible in Figure F13 where profile 48250420 crosses profile AWI 91090. Figure F14 shows the approximate maximum drill depth at the four Sites M0001-M0004.

Expedition 302 high-resolution seismic profiles add new information to the geophysical database. Based on previous multichannel seismic profiles, the uppermost $450-500 \mathrm{~m}$ of the Lomonosov Ridge sediments can be subdivided into four seismic stratigraphic units LR3-LR6 (Jokat et al., 1995) (Fig. F13). The base of unit LR3, the unconformity at the base of the Tertiary sediments, is a prominent reflector in the Expedition 302 profiles as well as in AWI-91090 (Fig. F13). In profile AWI-91090, there is an almost equally strong reflector some $100 \mathrm{~m}$ below the base of LR3. In the higher resolution Expedition 302 profiles, no reflector exists at this level. Similarly, in profile AWI-91090, there is a reflector $\sim 100 \mathrm{~m}$ below the seafloor that has no clear equivalent reflector in Expedition 302 seismic profiles. In AWI-91090, this prominent reflector is interpreted as the boundary between units LR5 and LR6 (Fig. F13). In Expedition 302 profiles, this interval is almost seismically transparent. The LR4/LR5 boundary is distinct in the AWI-91090 profile as well as in Expedition 302 profiles. In the AWI-91090 profile, there is again a reflection some $100 \mathrm{~m}$ below the LR4/LR5 boundary, interpreted as the boundary between units LR3 and LR4. In Expedition 302 profiles, this reflector is not present. Thus, only the unit boundary LR4/LR5 and the base of unit LR3 are identified in both Expedition 302 profiles and the AWI-91090 seismic line (Fig. F13).

The Cenozoic sequence in Expedition 302 profiles is subdivided into two seismic stratigraphic units, corresponding to LR5/LR6 and LR3/LR4. The seismic reflectors are essentially flat-lying throughout the entire section. The internal reflectors in the upper LR5LR6 unit are weak and discontinuous, indicating small impedance contrasts. Undulating reflectors at several levels suggest that the seafloor has, at times, been rather uneven. The basal part of Unit LR5-LR6 contains a unit of seismically stratified reflectors (Fig. F13). The true nature of these reflectors remains to be further explored through core-seismic integration.

In Expedition 302 profiles, the LR3-LR4 unit features a rather diffuse horizontal reflector in its middle part (Fig. F10). Slightly undulating reflectors occur in the lower and upper parts of this unit. Similar to the LR5-LR6 unit, the seafloor has evidently been rather uneven at times.

The LR3 reflector, marking the base of Cenozoic sediments on the Lomonosov Ridge (Jokat et al, 1995), appears to be complicated and composed of reflections from two or more sediment surfaces. The erosional unconformity, sculptured in bedrock, is rough. Subsequent infilling of this irregular surface has created the flat strong reflector seen in Expedition 302 data (Fig. F10).

\section{Summary}

During the past four decades, significant efforts have been made to collect seismic reflection data over prominent features in the central Arctic Ocean. These efforts are noteworthy because of the difficulties in conducting operations in sea-ice-covered waters. Seismic data quality collected over the Lomonosov Ridge have significantly improved from the 1960-1980 ice island data, where only a thin sediment cover was detected, to the modern icebreaker surveys (with robust survey methodologies), where the true nature of the thick sediment cover has been imaged.

The Arctic 1991 expedition collected the first highquality seismic reflection data on the Lomonosov Ridge. These data formed the foundation of the proposed Expedition 302 program. Subsequent surveys (1996, 1998, 2001, and during Expedition 302) contributed to these data, resulting in a more complete geophysical interpretation of the Lomonosov Ridge, which is now being calibrated by the results from Expedition 302.

\section{References}

Andersen, L.G., and Carlsonn, M.L. (Eds.), 1992. Swedish Arctic Research Programme 1991-International Arctic Ocean Expedition, Icebreaker Oden-A Cruise Report: Stockholm (Polarforskningssekretariatet).

Backman, J., Jakobsson, M., Knies, J., Knutsen, J.O., Kristoffersen, Y., Lif, A., Musatov, E., and Stein, R., 1997. Geological coring and high resolution chirp sonar profiling. In Grönlund, E. (Ed.), Polarforskningssekritariatets Årsbok 1995/96: Stockholm (Polarforskningssekretariatet), 6466.

Blasco, S.M., Bornhold, B.D., and Lewis, C.F.M., 1979. Preliminary results of surficial geology and geomorphology 
studies of the Lomonosov Ridge, central Arctic Basin. Pap-Geol. Surv. Can., 79-1C:73-83.

Chayes, D., Coakley, B.J., Langseth, M.G., Anderson, R.M., DiBella, G., Rognstad, M.R., Davis, R.B., Edwards, M., Kosalos, J.G., and Szender, S.J., 1996. SCAMP: an enhanced geophysical mapping system for Arctic submarine cruises. Eos, Trans. Am. Geophys. Union, 77(46):F315. (Abstract)

Edwards, M.H., and Coakley, B.J., 2003. SCICEX investigations of the Arctic Ocean system. Geochemistry, 63(4):281-392.

Fütterer, D.K., 1992. ARCTIC '91: the expedition ARK VIII/ 3 of RV Polarstern in 1991. Ber. Polarforsch., 107:1-267.

Grantz, A., Mann, D.M., and May, S.D., 1986. Multichannel seismic-reflection data collected in 1978 in the eastern Chukchi Sea. Open-File Rep.-U.S. Geol. Surv., 86206:1-3.

Jackson, H.R., Forsyth, D.A., and Hall, J.K., 1990. Seismic reflection and refraction. In Grantz, A., Johnson, L., and Sweeney, J.F. (Eds.), The Geology of North America: The Arctic Ocean Region (Vol. L): Boulder (Geol. Soc. Am.), 134-153.

Jakobsson, M., 1999. First high-resolution chirp sonar profiles from the central Arctic Ocean reveal erosion of Lomonosov Ridge sediments. Mar. Geol., 154:111-123. doi:10.1016/S0025-3227(98)00186-8

Jakobsson, M., Cherkis, N., Woodward, J., Coakley, B., and Macnab, R., 2000. A new grid of Arctic bathymetry: a significant resource for scientists and mapmakers. Eos, Trans. Am. Geophys. Union, 81(9):89, 93, 96.

Jakobsson, M., Løvlie, R., Arnold, E., Backman, J., Polyak, L., Knudsen, J.-O., and Musatov, E., 2001. Pleistocene stratigraphy and paleoenvironmental variation from Lomonosov Ridge sediments, central Arctic Ocean. Global Planet. Change, 31(1-4):1-2. doi:10.1016/S09218181(01)00110-2

Jokat, W., 1998. Arctic '98: the expedition ARK-XIV/1a of RV Polarstern in 1998. Ber. Polarforsch., 308:1-159.

Jokat, W., 2003. Seismic investigations along the western sector of Alpha Ridge, central Arctic Ocean. Geophys. J. Int., 152:185-201. doi:10.1046/j.1365246X.2003.01839.X

Jokat, W., Uenzelmann-Neben, G., Kristoffersen, Y., and Rasmussen, T.M., 1992. Lomonosov Ridge-a doublesided continental margin. Geology, 20(10):887-890. doi: $10.1130 / 0091-$

7613(1992)020<0887:LRADSC>2.3.CO;2

Jokat, W., Weigelt, E., Kristoffersen, Y., Rasmussen, T., and Schöne, T., 1995. New insights into the evolution of the Lomonosov Ridge and the Eurasian Basin. Geophys. J. Int., 122:378-392.

Kristoffersen, Y., Berge, H., and Grinheim, E., 2001. An ODP-site survey on Lomonosov Ridge during Arctic Ocean 2001. In Grönlund, E. (Ed.), Polarforskningssekretariatet Årsbok 2001: Stockholm (Polarforskningssekretariatet), 64-66.

Kristoffersen, Y., Buratvtsev, V., Jokat, W., and Poselov, V., 1997. Seismic reflection surveys during Arctic Ocean 1996. In Grönlund, E. (Ed.), Polarforskningssekretariatet Årsbok 1995/96: Stockholm (Polarforskningssekretariatet), 75-77.

Newton, G.B., 2000. History, achievements and the future of SCICEX: The Science Ice Exercise Program. Hydro Int., 14:2-7.

Ostenso, N.A., and Wold, R.J., 1977. A seismic and gravity profile across the Arctic Ocean Basin. Tectonophysics, 37:1-24. doi:10.1016/0040-1951(77)90036-1

Polyak, L., Edwards, M.H., Coakley, B.J., and Jakobsson, M., 2001. Ice shelves in the Pleistocene Arctic Ocean inferred from glaciogenic deep-sea bedforms. Nature (London, U. K.), 410:453-457. doi:10.1038/35068536

Rudels, B., Anderson, L.G., and Jones, E.P., 1996. Formation and evolution of the surface mixed layer and halocline of the Arctic Ocean. J. Geophys. Res., 101:88078821. doi:10.1029/96JC00143

Weber, J.R., 1979. The Lomonosov Ridge experiment: 'LOREX 79'. Eos, Trans. Am. Geophys. Union, 60(42):715721.

Weber, J.R., and Roots, E.F., 1990. Historical background: exploration, concepts, and observations. In Grantz, A., Johnson, G.L., and Sweeney, J.F. (Eds.), The Geology of North America: The Arctic Ocean Region (Vol. L): Boulder (Geol. Soc. Am.), 5-36.

Weber, J.R., and Sweeney, J.F., 1985. Reinterpretation of morphology and crustal structure in the central Arctic Ocean. J. Geophys. Res., 90(B1):663-677.

Publication: 7 March 2006

MS 302-102 
Figure F1. Map showing the accumulated geophysical database covering the Lomonosov Ridge. Bathymetry is from the International Bathymetric Chart of the Arctic Ocean (Jakobsson et al., 2000). A local track chart near Expedition 302 Sites M0001-M0003 is shown in Figure F7. The limit of this track chart is indicated by a yellow box.

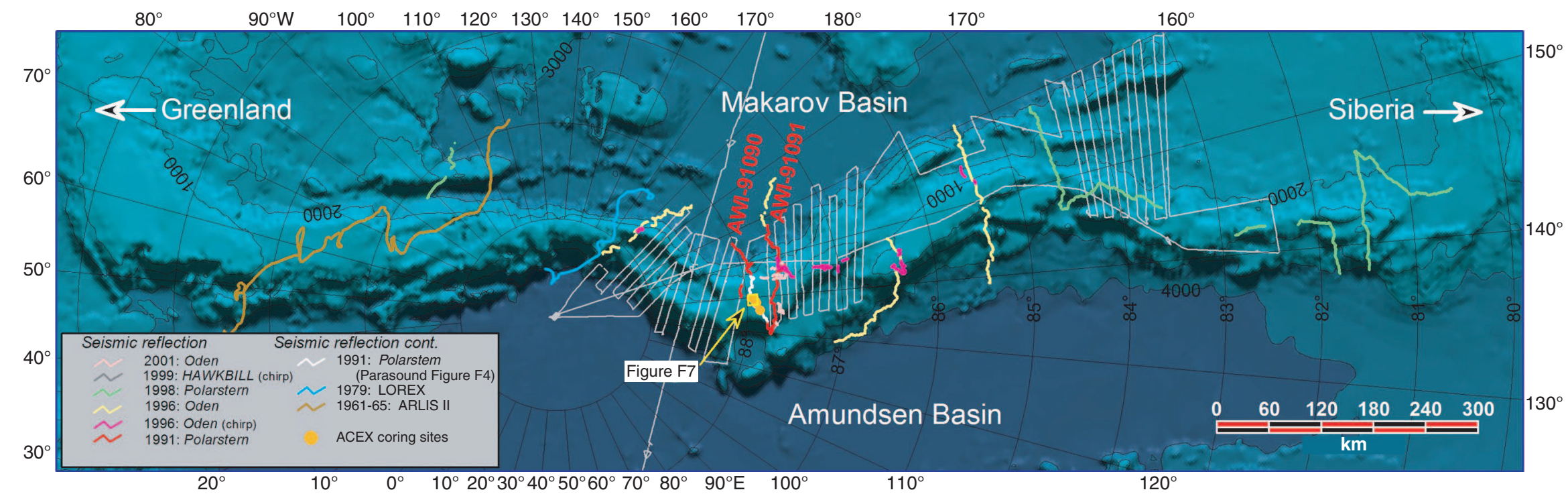


Figure F2. LOREX seismic reflection profile crossing the Lomonosov Ridge near the North Pole. Modified from Jackson et al. (1990).

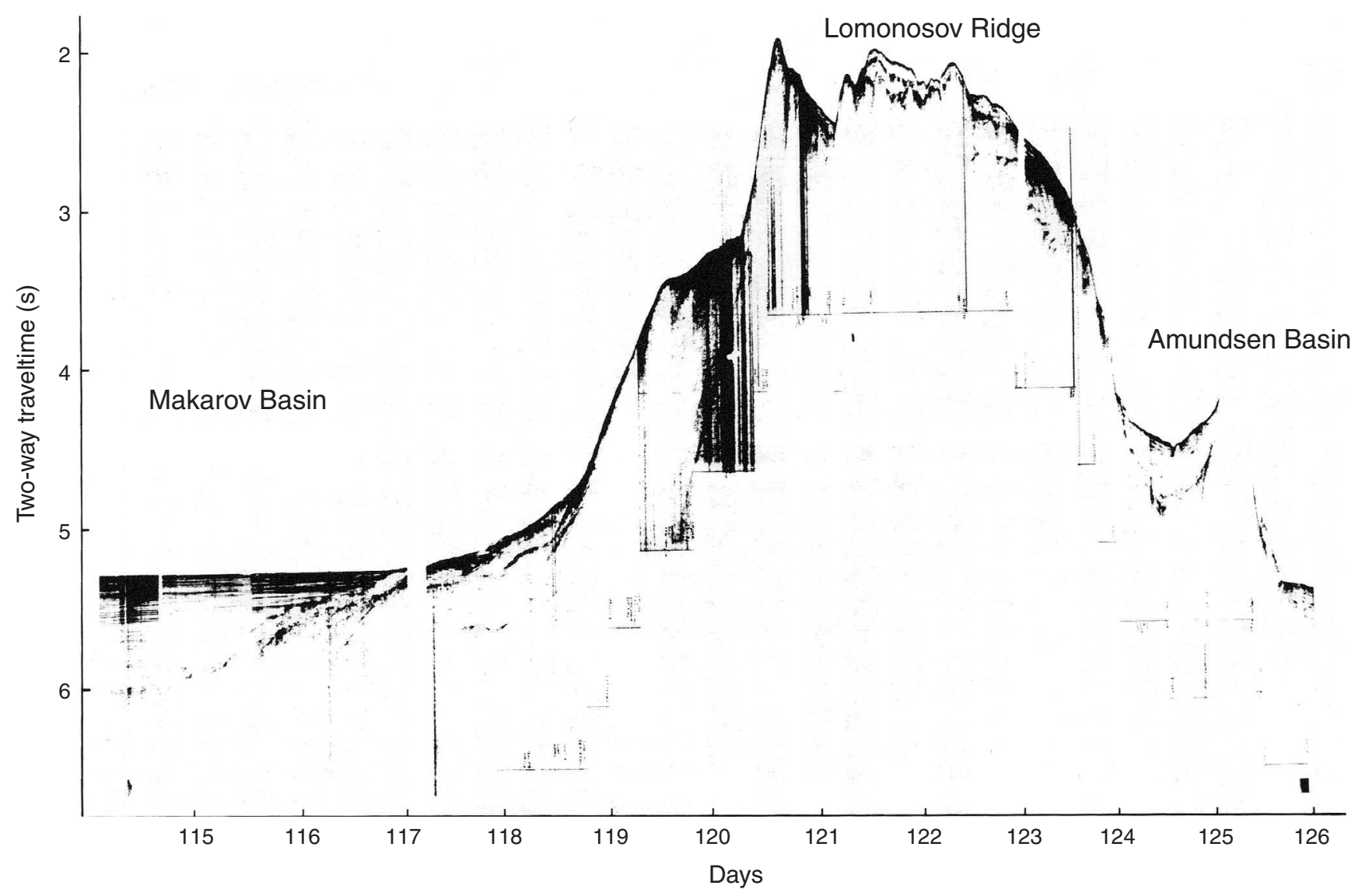


Figure F3. Seismic reflection profile AWI-91091 (Jokat et al., 1992, 1995). Location of profile shown in Figure F1 (figure courtesy of Wilfried Jokat, Alfred Wegener Institute).

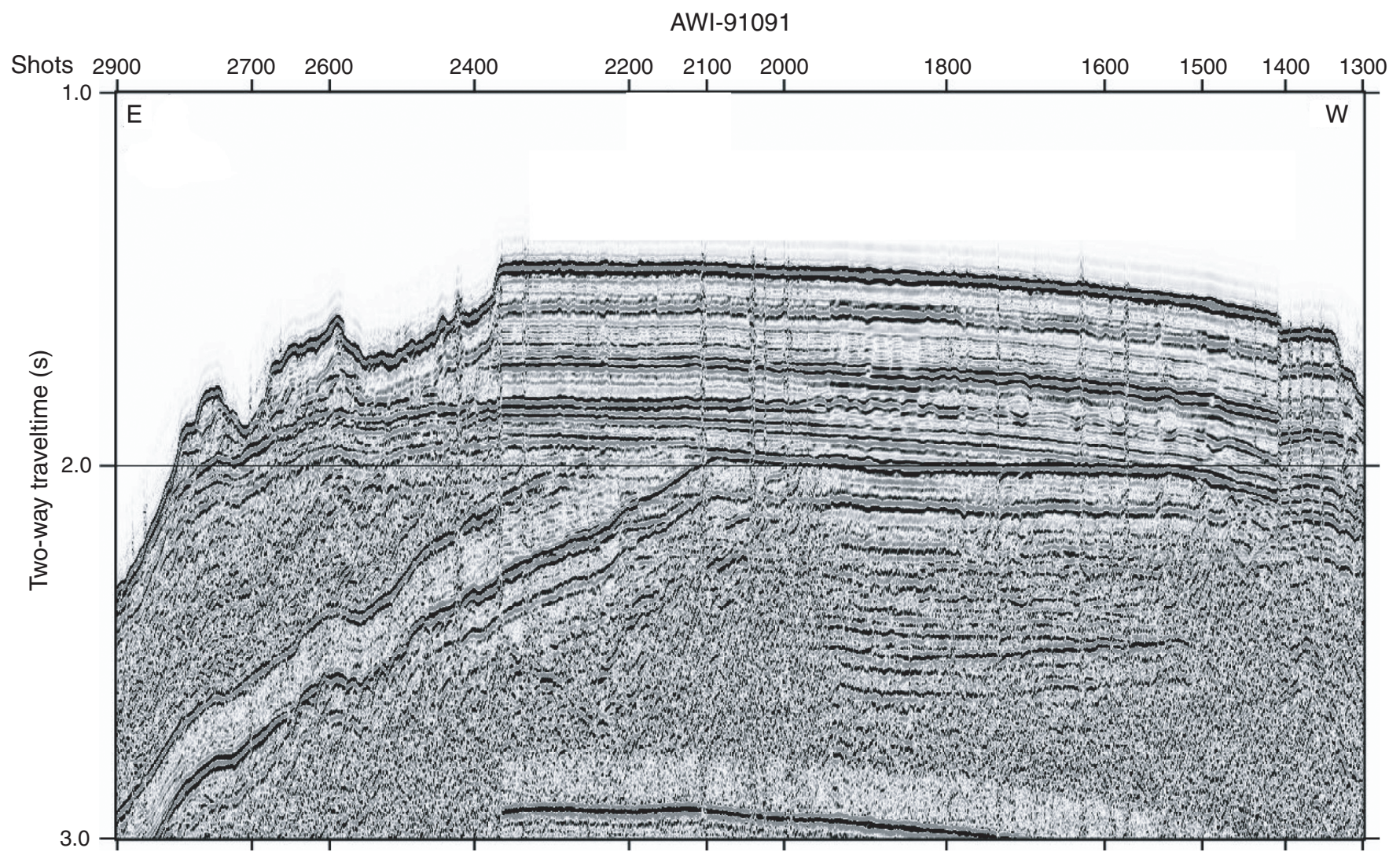


Figure F4. Parasound high-resolution subbottom profile crossing the Lomonosov Ridge crest. As shown in Figure F1, the profile (white line) is located along the segment of seismic reflection profile AWI-91090 (red line) (figure courtesy of David Mosher, Geological Survey of Canada).

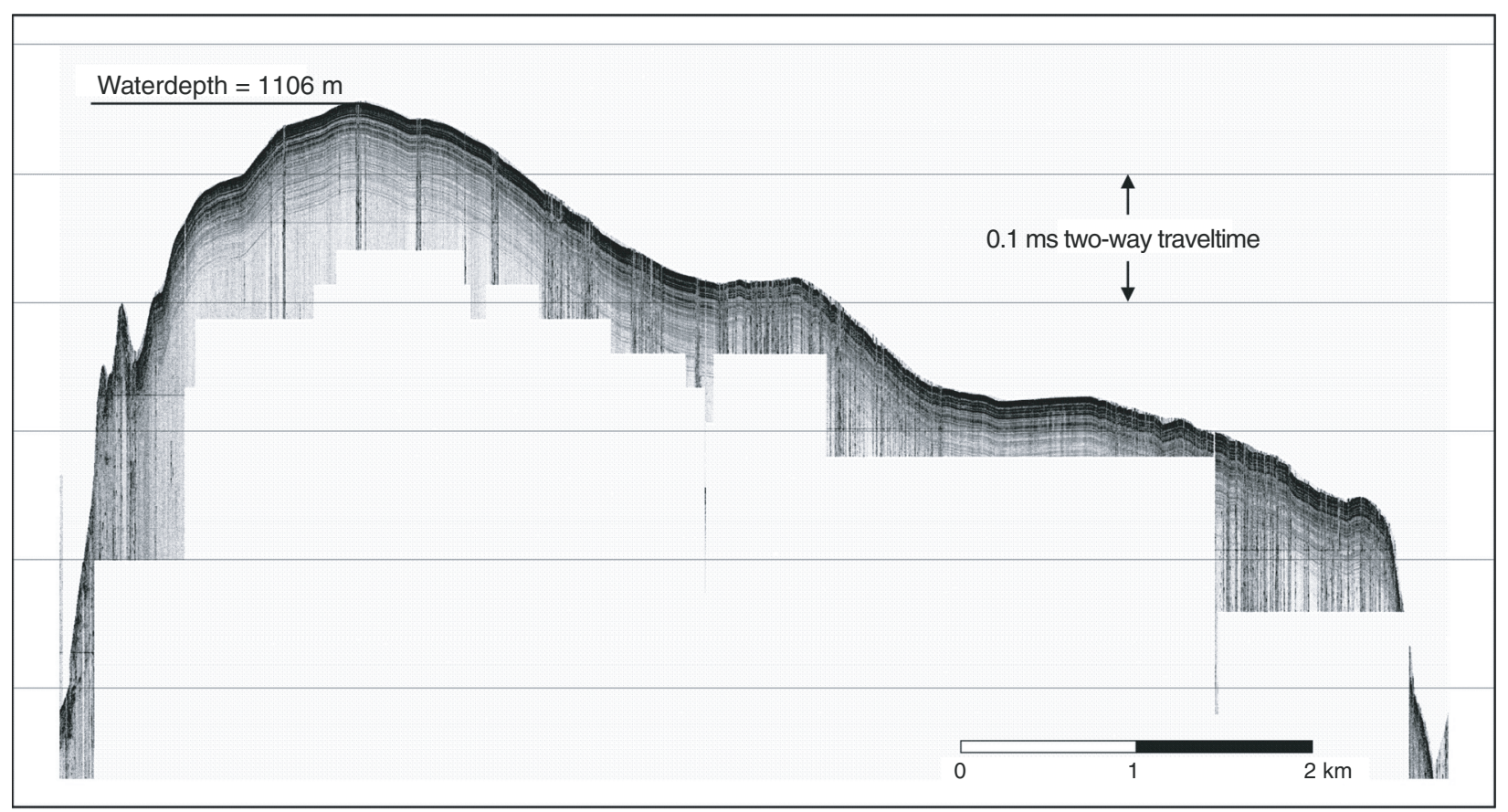


Figure F5. Chirp sonar records of the Lomonosov Ridge crest (Jakobsson, 1999). Black arrows mark prominent reflectors used by Jakobsson (1999) to subdivide the stratigraphy into seismoacoustic units. A. Profile showing the substantial erosion that was mapped in water depths shallower than $1 \mathrm{~km}$. A pronounced unconformity due to the erosion is indicated with a white arrow. B. Profile acquired in water depths deeper than $1 \mathrm{~km}$, showing an apparently undisturbed sediment stratigraphy within the resolution of the chirp sonar (20-40 $\mathrm{cm})$.
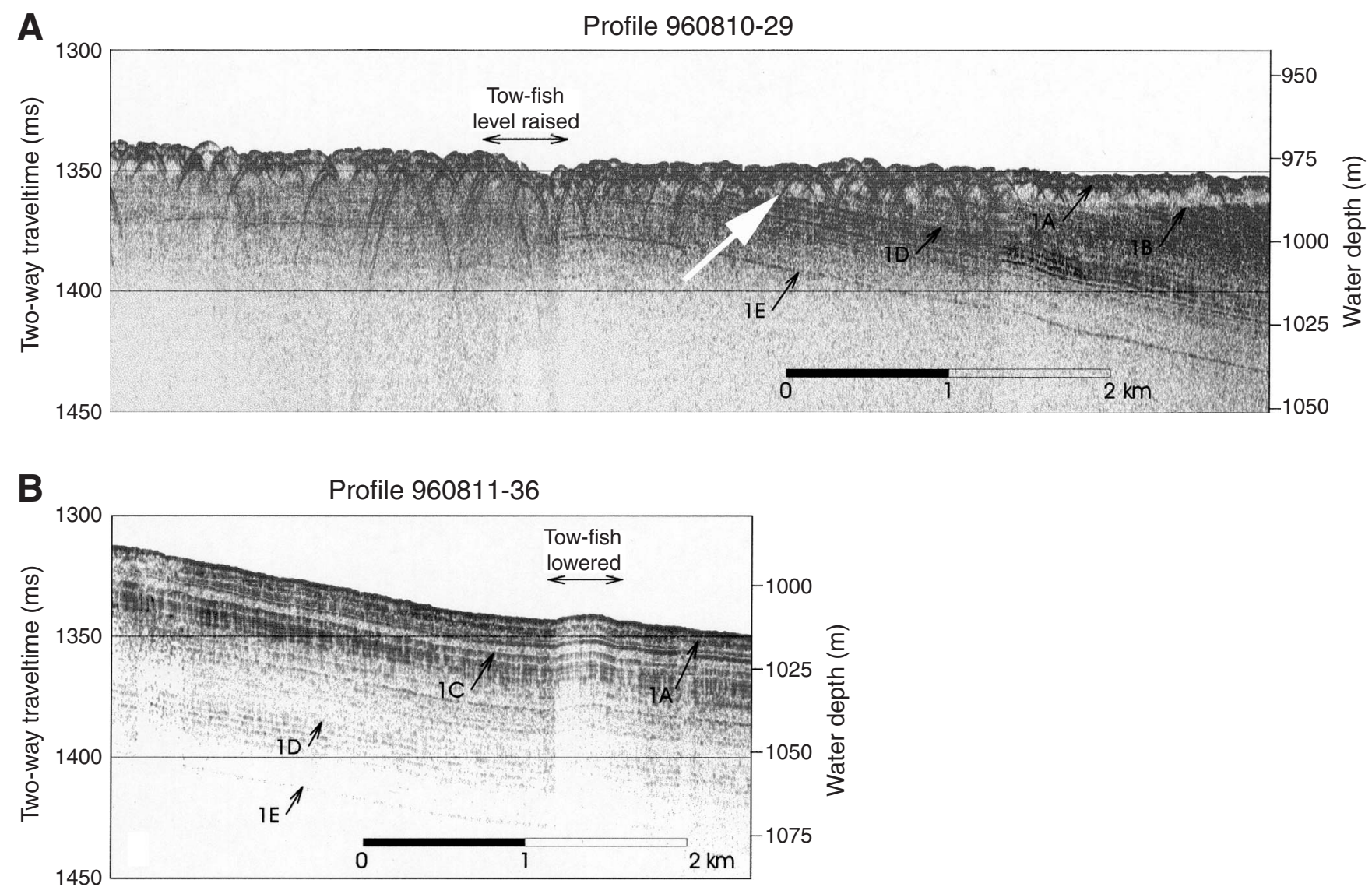
Figure F6. Seismic reflection profile AWI-98590 collected during the ARK-XIV/1a expedition in 1998 (figure courtesy of Wilfried Jokat, Alfred Wegener Institute).

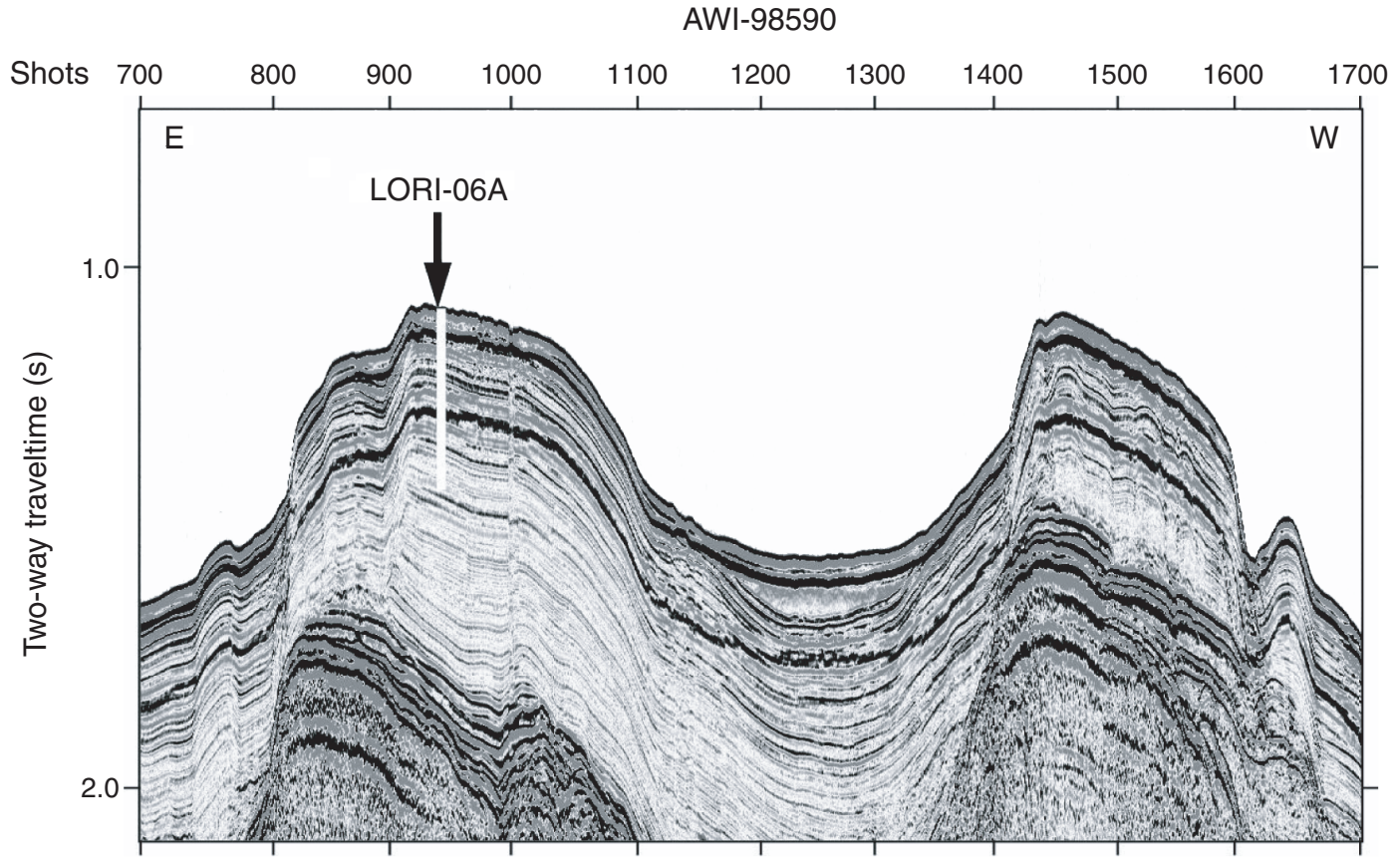


Figure F7. Track chart showing the planned (grey straight line) and surveyed (black "wiggly" line) seismic reflection profiling during Expedition 302. The red line shows seismic reflection profile AWI-91090 (Jokat et al., 1992, 1995). Dark and light blue lines indicate profiles shown in Figure F10. The outline of the track chart is shown in Figure F1 (yellow box). GIS = geographic information system.

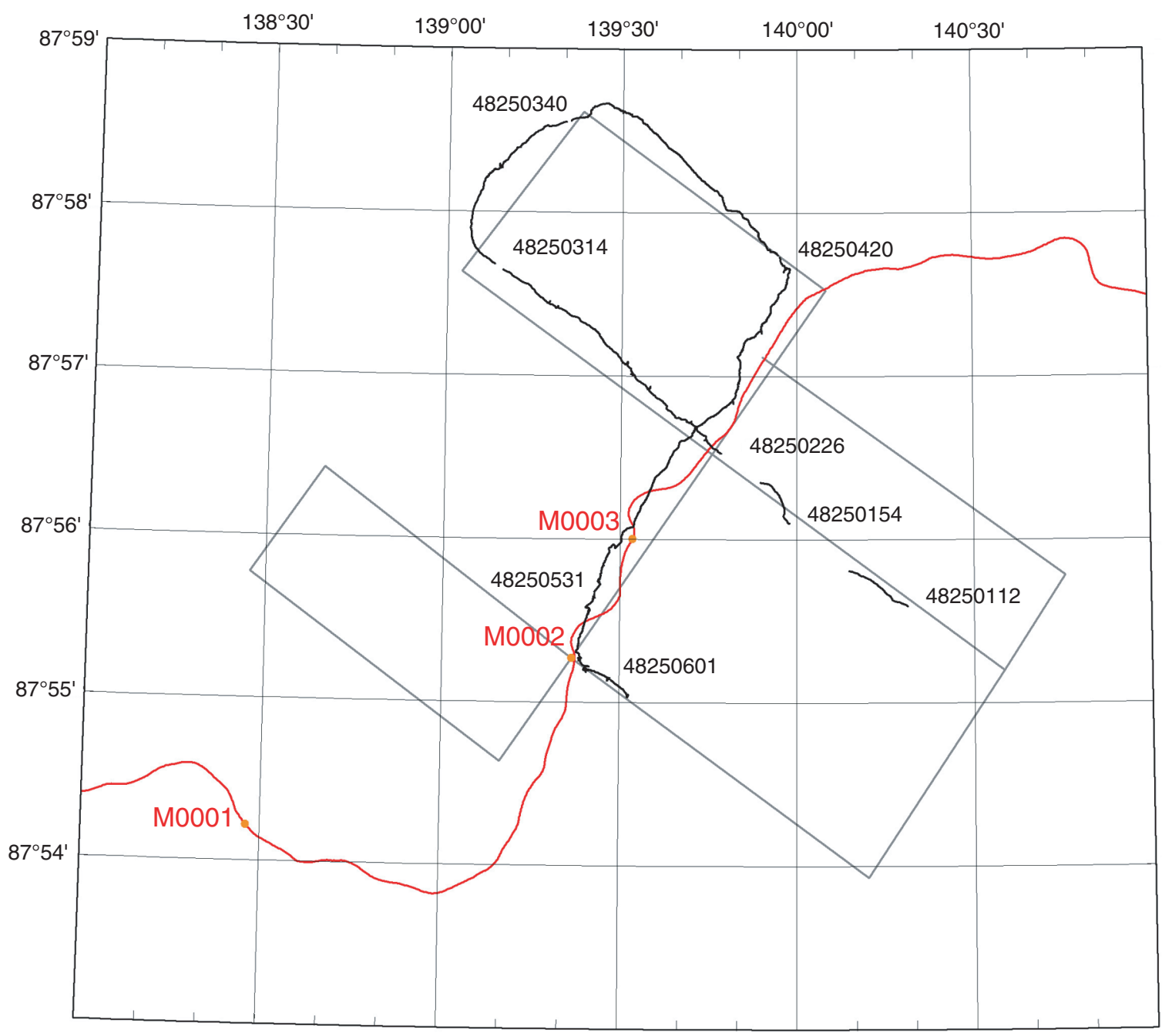


Figure F8. Expedition 302 seismic reflection system setup.

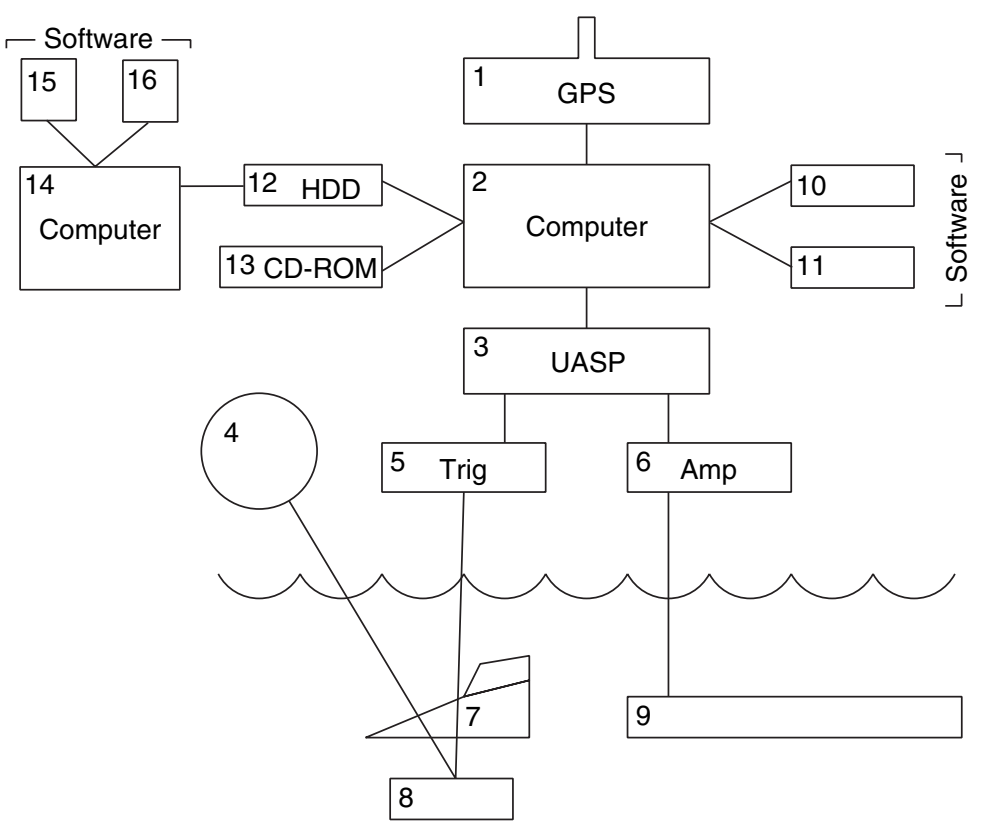

1) Ashtech G12 GPS

2) $P C$ computer

3) Meridata data acquision unit

4) Compressor $1600 \mathrm{l} / \mathrm{m}$

5) Air gun trigger

6) Signal amplifier

7) Instrument depressor

8) PAR air gun, 40 inch $^{3}$

9) One channel hydrophone $(20 \mathrm{~m})$

10) MDCS - Meridata data acquision

11) MDPS - Meridata processing and interpretation

12) Hard disk drive

13) CD-ROM

14) $P C$ computer

15) Geomedia Professional GIS

16) Fledermaus (3-D visualization) 
Figure F9. Steel depressor manufactured by Bertil Sjölund (welder on the Oden) for towing the seismic source and receiver.

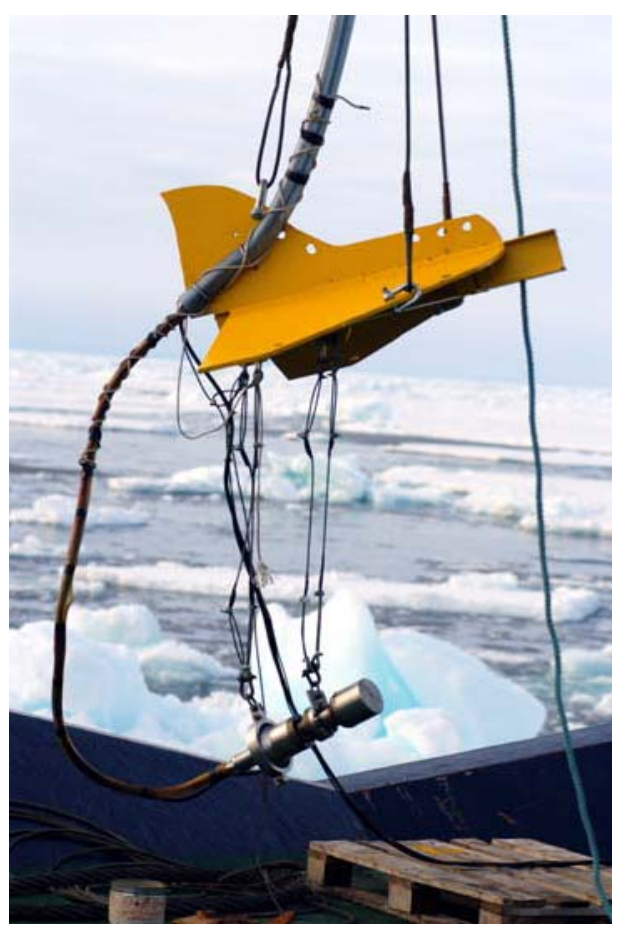


Figure F10. Seismic reflection profiles (A) 48250420 and (B) 48250531 . See Figure F7 for the location of the profiles. Because of the high level of ship noise recorded together with the seismic reflections, a 10-fold running stack was applied to the seismic recordings. No band-pass filtering was applied, but a $20 \mathrm{~Hz}, 6 \mathrm{db}$, highpass filter was applied to reduce hydrophone towing noise and low-frequency ship noise. The intermittent reduction of the ship's speed to below $0.5 \mathrm{kt}$ caused the hydrophone to temporarily sink to a near vertical position. This resulted in recording periods when a wavy seismic record resulted. When the hydrophone was positioned properly, the data showed the true nature of the relatively flat seafloor reflection. Approximately $0.5 \mathrm{~s}$ below the seafloor reflector and slightly above the unconformity reflector, a faint ghost reflection of the seafloor is apparent. This is possibly an instrument artifact caused by the delayed closure of the air gun related to the wave shape kit. However, this artifact does not obscure the profiles enough to limit interpretations.
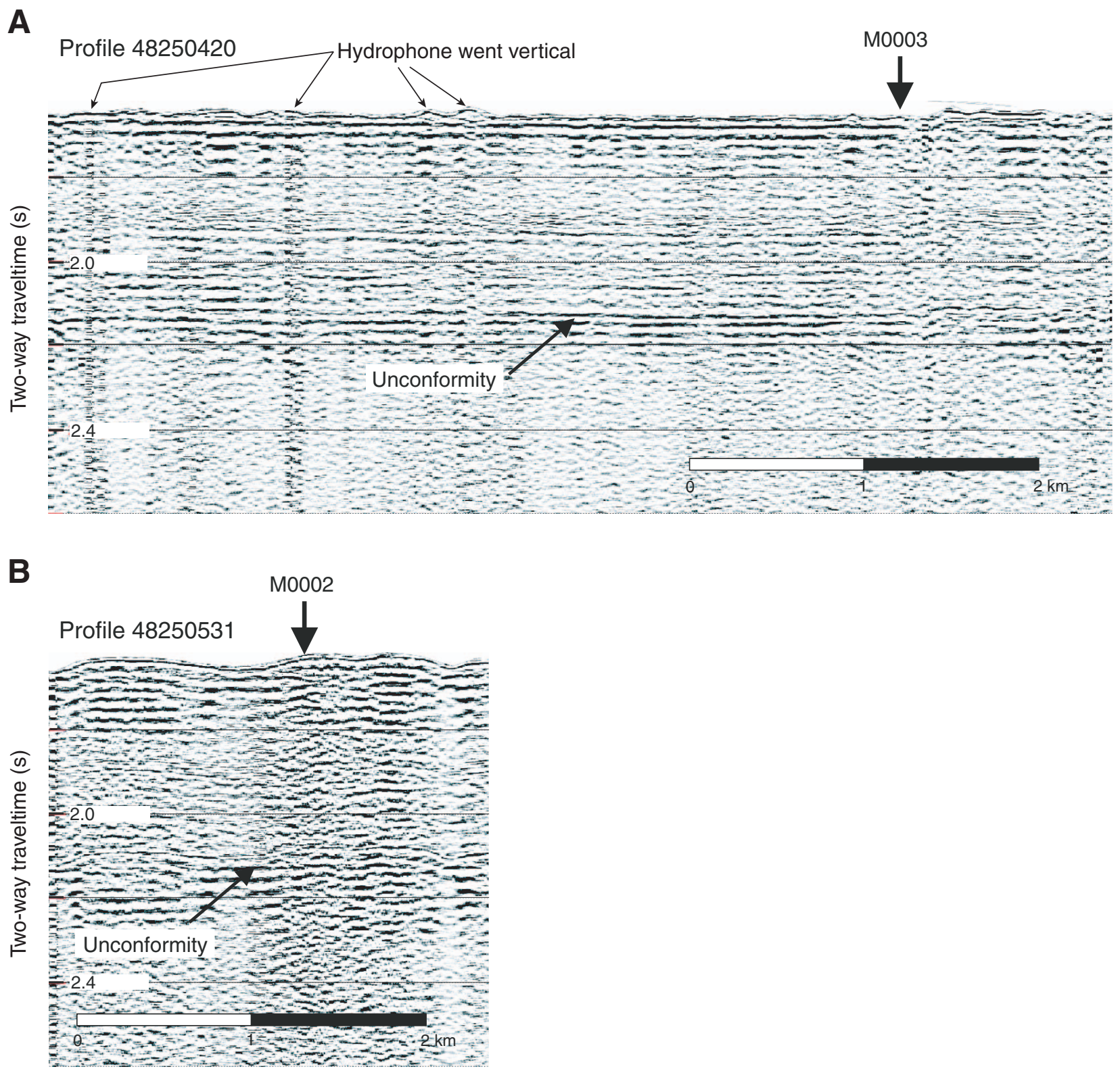
Figure F11. Oden track lines around Expedition 302 drill sites.

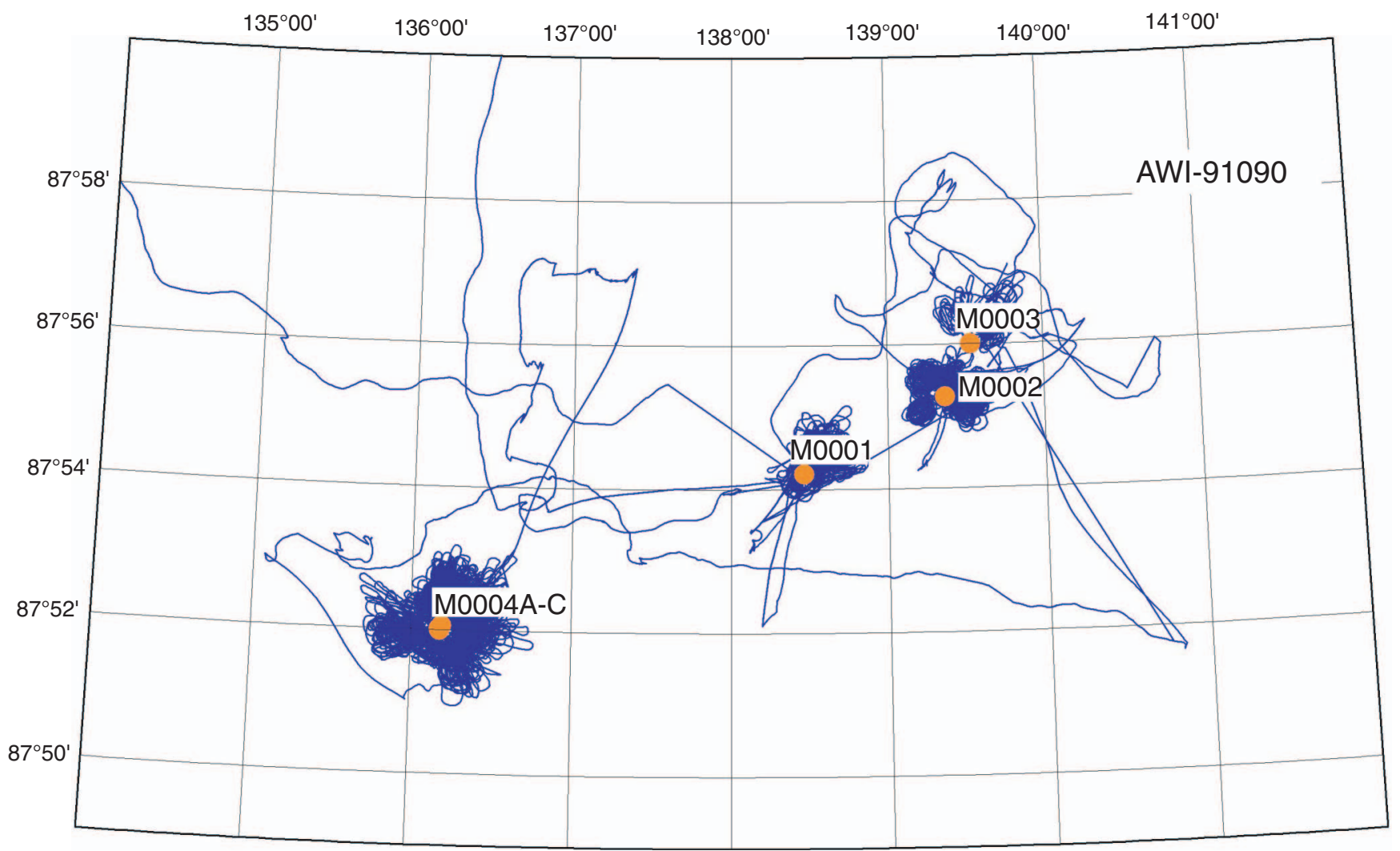


Figure F12. 3-D analysis of collected echo sounding data in the vicinity of Site M0002. The data points shown are the remainder after substantial outliers have been removed. Nevertheless, the large spread of the depth values (1000-1400 m) is merely a result of a poorly functioning echo sounder revealed from cross-over analysis as well as comparison with previous multibeam surveys using Polarstern's Hydrosweep system (Fütterer, 1992).

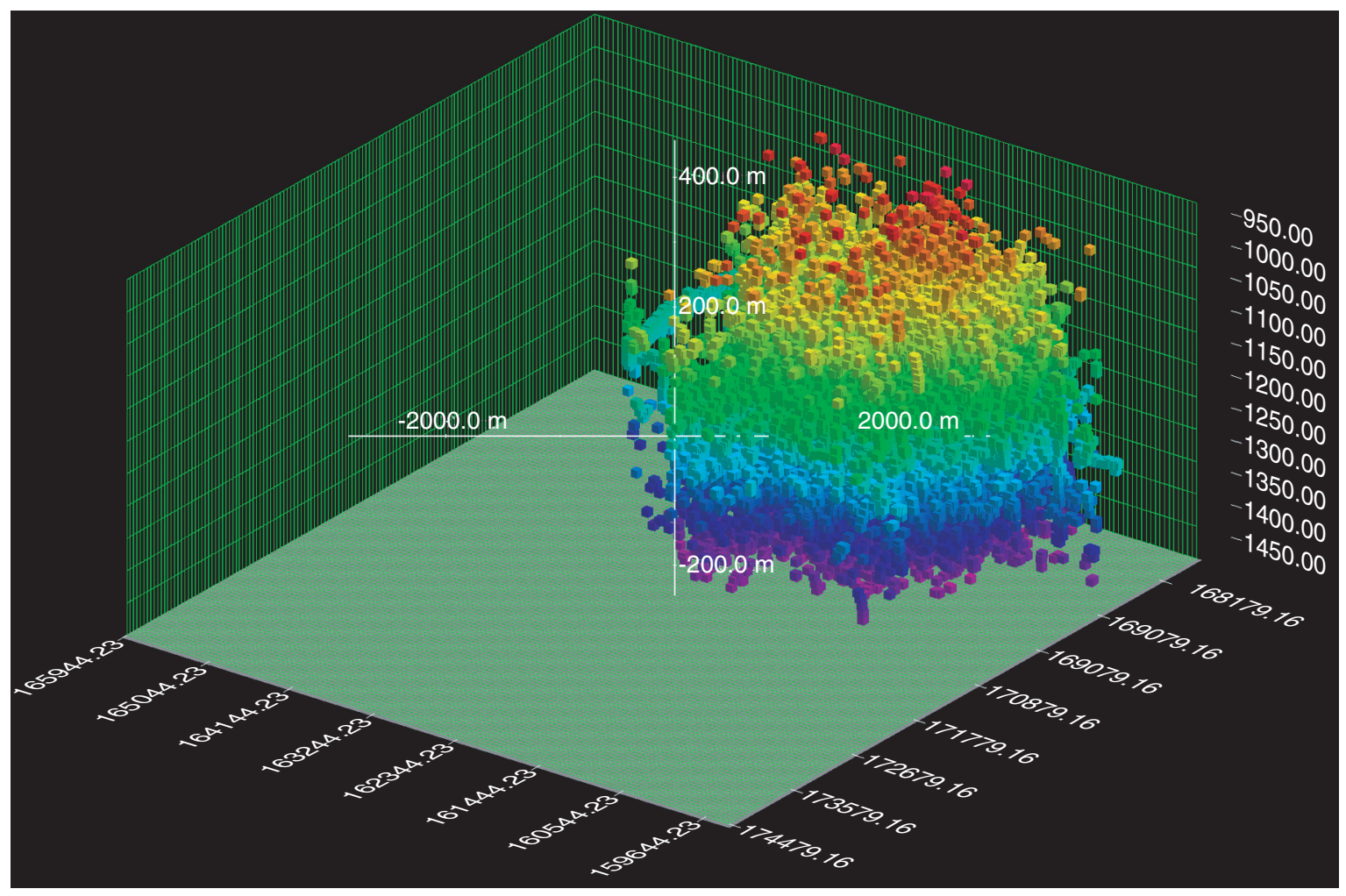


Figure F13. 3-D view of seismic profiles near drill Sites M0001-M0003. Note that only a section of AWI-91090 and profiles 48250420 and 4820531 are shown. The black arrow indicates high-frequency reflectors in the lower part of Unit LR5.

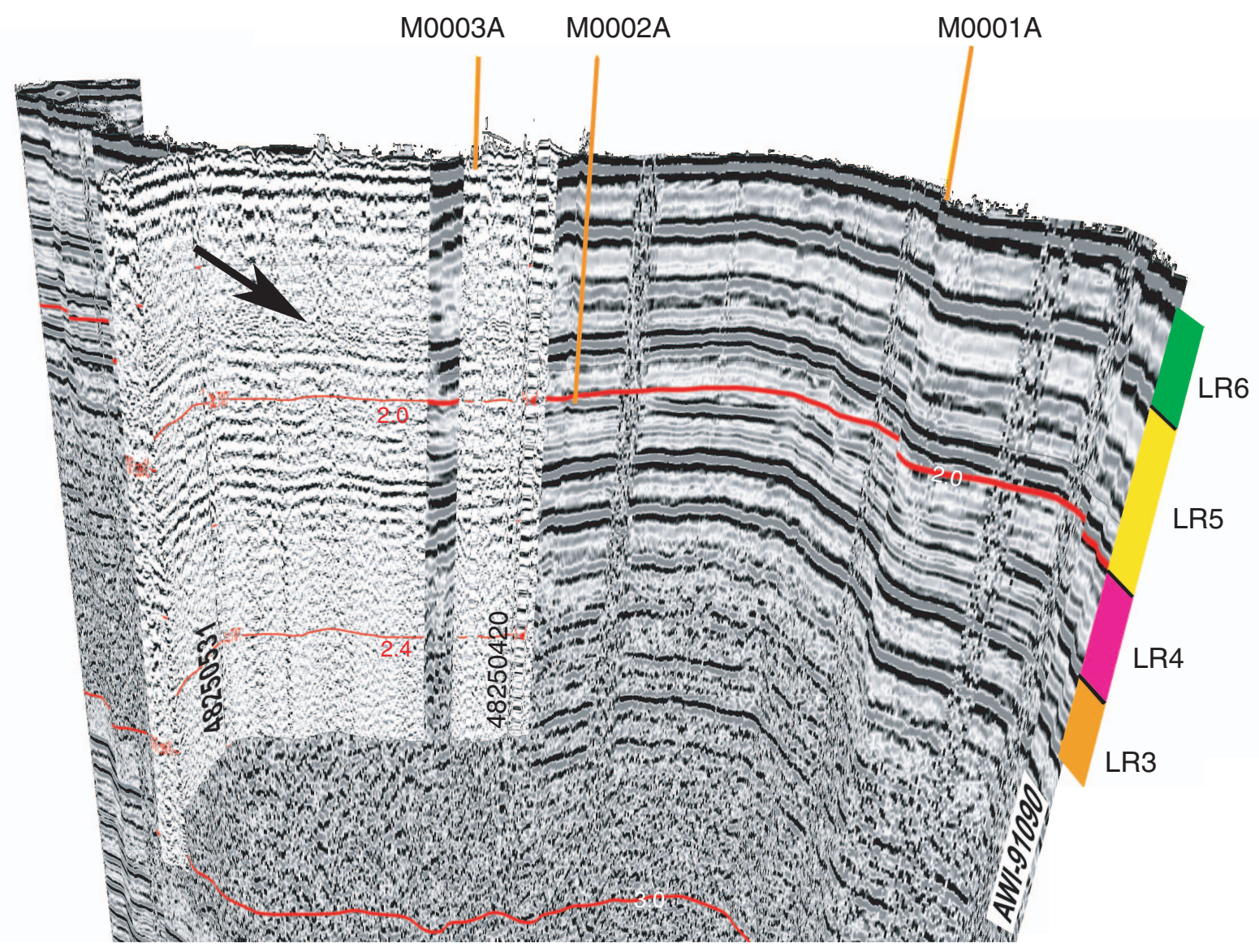


Figure F14. Section of seismic reflection profile AWI-91090 and the locations of Expedition 302 drill sites (red bars). The length of each red bar represents the depth of penetration in relation to the seismic reflection profile. The core penetration depths at each site were converted from core depth in meters to two-way travel time using sediment $P$-wave velocities logged with a Multi Sensor Core Logger onboard the drillship Vidar Viking.

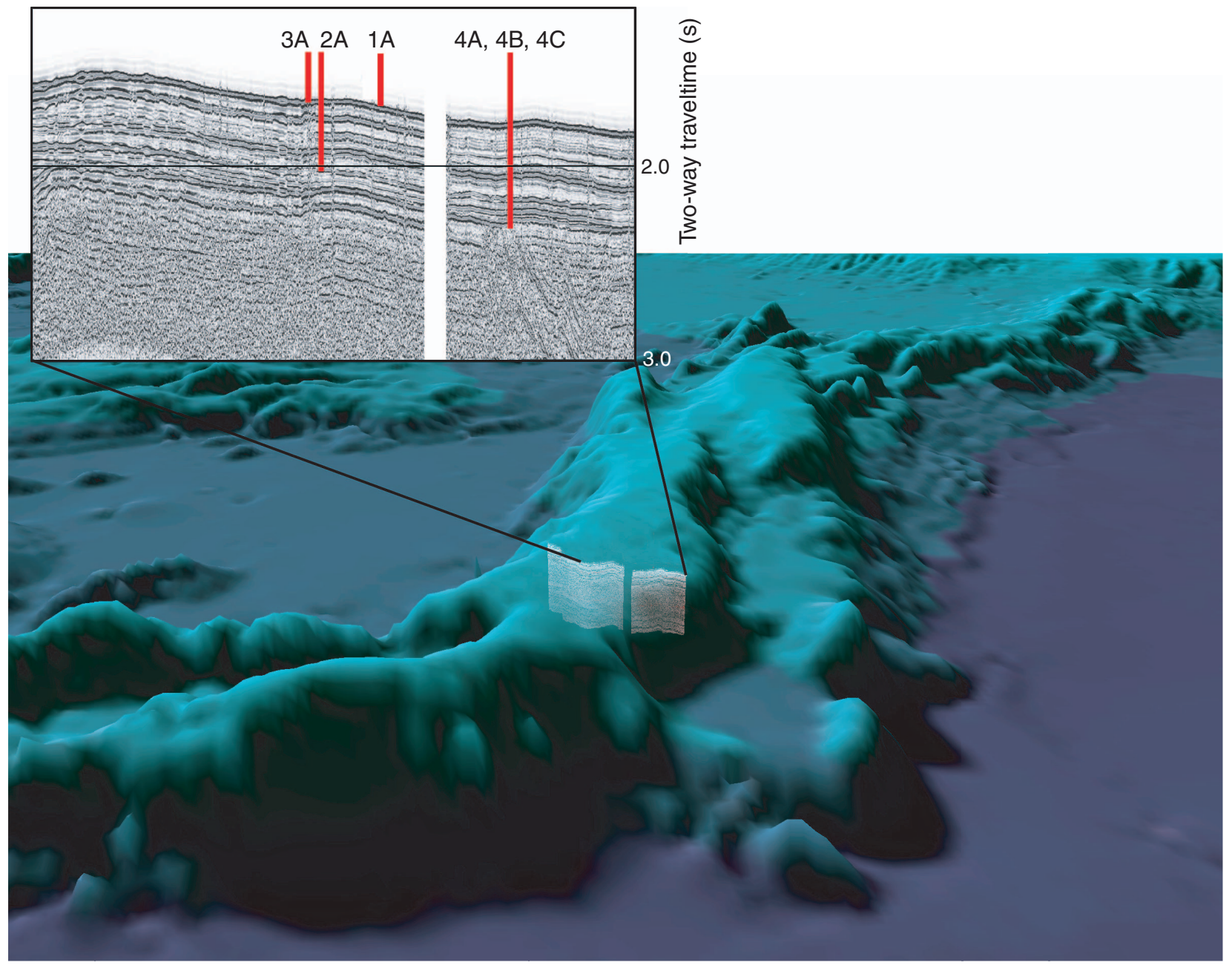

